\title{
Fire Research Publications, 1976
}

Nora H. Jason

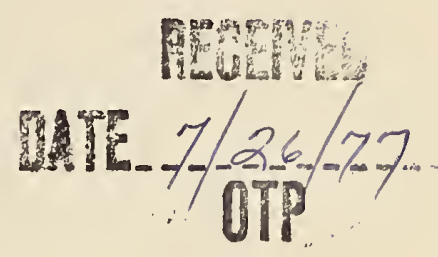

Center for Fire Research

Institute for Applied Technology

National Bureau of Standards

Washington, D.C. 20234

July 1977

Final Report

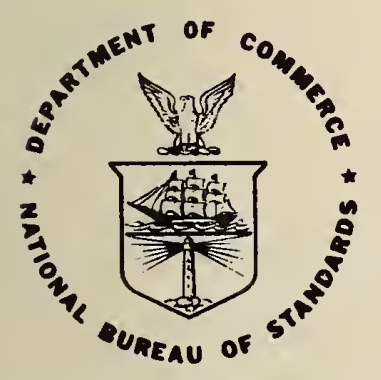

U. S. DEPARTMENT OF COMMERCE

NATIONAL BUREAU OF STANDARDS 

NBSIR 77-1277

\section{FIRE RESEARCH PUBLICATIONS.} 1976

Nora H. Jason

Center for Fire Research Institute for Applied Technology National Bureau of Standards

Washington, D.C. 20234

July 1977

Final Report

U.S. DEPARTMENT OF COMMERCE, Juanita M. Kreps, Secretary

Dr. Sidney Harman, Under Secretary

Jordan J. Baruch. Assistant Secretary for Science and Technology

NATIONAL BUREAU OF STANDARDS, Ernest Ambler, Acting Director 

"Fire Research Publi.cations, 1976" is a supplement to the previous editions which covered the years 1969-1972 (NBSIR 73-246, NTIS Order No. COM-74-10989; \$3.25), 1973 (NBSIR 74-511, NTIS Crder No. COM-74-11448; \$3.25), 1974 (NBSIR 75-736, NTIS Order No. COM-75-1.1018; $\$ 3.25$ ), and 1975 (NBSIR 76-1120, NTIS Order No. PB-257837; \$3.50). Only publications prepared by the members of the Center for Fire Research (CFR), by other National Rureau of Standards (NBS) personnel or external laboratories under contract or grant from the CFR are cited. Articles published in NBS house organs also are cited.

For documents that are available for purchase from either the Government Printing Uffice (GPO) or the National Technical Information Service (NTIS), the specific order number and paper copy price (prices are subject to change) have been included in the citation.

GPO documents are obtained by writing directly to the Superintendent of Documents, U.S. Government Printing office, Washington, D.C. 20402. Indicate the SD Catalog No. for each document requested. Orders must be prepaid. Remittance should be made by check or money order payable to the "Superintendent of Dccuments, U.S. Government Printing office".

NTIS documents are cbtained by writing directly to the National Technical Information Service, U.S. Department of Commerce, Springfield, Virginia 22161. Indicate the NTIS Order No. for each document requested. Microfiche copies of the documents also are available at a cost of $\$ 3.00$ for domestic orders. Al1 prices are subject to change. orders must be prepared by check or money order payable to "National Technical Informatior. Service" or by utilizing an NTIS Form with your deposit account number. 


\section{Contents}

Page

I. Journal Articles and Conference Proceedings

II. National Bureau of Standards Publications

A. National Bureau of Standards Dimensions 3

B. National Bureau of Standards Interagency 4 Reports

III. Contract and Grant Reports 6

IV. Author Index 8 
Benjamin, I. A. Development of a Room Fire Test. In: Fire Standards and Safety. Proceedings, pp. 300-311. National Bureau of Standards and the American Society for Testing Materials, Gaithersburg, MD., Apri1 5-6, 1976. ASTM STP 614 (1977).

Benjamin, I. A. and Adams, C. H. The Flooring Radiant Panel Test and Proposed Criteria. Fire Journa1, Vo1. 70, No. 2, 63-70, March 1976.

Birky, M. M. Philosophy of Testing for Assessment of Toxicological Aspects of Fire Exposure. Journal of Combustion Toxicology, Vol. 3, 6-23, February 1976.

Birky, M. M., Coats, A. W., Alderson, S. E., Brown, J. E. and Pitt, B. New Measurements and Observations of the Toxicological Hazard of Fire in a Metrorail Interior Mock-up. Fireline, 9-13, October 1976.

Breden, L. H. and Meisters, M. The Effect of Sample Orientation in the Smoke Density Chamber. Journal of Fire and Flammability, Vol. 7, 234-247, Apri1 1976.

Bright, R. G. Early Warning Fire Detection. In: Fire Protection in Interior Design. Proceedings, pp. 170-184. Cleveland State University, Ohio, April 10-11, 1975 (1976).

Bright, R. G. Status and Problems of Fire Detection for Life Safety in the United States. In: Fire Detection for Life Safety. Proceedings, pp. 3-14. National Academy of Sciences-National Research Council, Washington, D.C., March 31 and April 1, 1975 (1976).

Clarke, III, F. B. and Ottoson, J. Fire Death Scenarios and Firesafety Planning. Fire Journal, Vol. 70, No. 3, 20-22; 117-118, May 1976.

Davis, S. Interior Furnishings and the Fire Problem. In: Fire Protection in Interior Design. Proceedings, pp. 137-148. Cleveland State University, Ohio, April 10-11, 1975 (1976).

Einhorn, I. N., Birky, M. M., Hileman, F. D., Ramakrishman, M. S., Ryan, P. W., Voorhees, K. J. and Wojcik, L. H. Computerized Analytical System for the Analysis of Thermal Decomposition Products. In: Physiological and Toxicological Aspects of Combustion Products: International Symposium. Proceedings, pp. 181-214. National Academy of Sciences- National Research Council, Salt Lake City, Utah, March 18-20, 1974 (1976). 
Fang, J. B. Measurements of the Behavior of Incidential Fires in a Compartment. Journal of Fire and Flammability, Vol. 7, 368-386, July 1976.

Fung, F. C. S. Smoke Simulation Studies of Pressurized Buildings. In: Fire Protection in Interior Design. Proceedings, pp. 44-64. Cleveland State University, Ohio, April 10-11, 1975 (1976).

Gann, R. G. and Cheng, I. T. Flow Study of Smoldering Charcoal. American Chemical Society, 172nd National Meeting, Division of Organic Coatings and Plastics, Preprint No. 20, San Francisco, California, September 1976.

Gross, D. The Measurement and Correlation of Fire Growth in a Room. In: Full-Scale Fire Tests Symposium, Armstrong Research and Development Center. Proceedings, pp. 77-87. Lancaster, Pa. November 11-12, 1974 (1976).

Kashiwagi, T. and Newman, D. L. Flame Spread Over an Inclined Thin Fuel Surface, Combustion and Flame, Vo1. 26, 163-177, 1976.

Krasny, J.F., Braun, E. and Peacock, R. Synthesis of a General Apparel Flammability Standard. In: Information Council on Fabric Flammability, 10th Annual Meeting. Proceedings, pp. 171-184. New York, December 8-9, 1976 (19.77).

Levin, B. Psychological Characteristics of Fire Setters. Fire Journal, Vo1. 70, No. 2, 36-41, March 1976; Fire and Arson Investigator, Vol. 27, No. 3, 12-22, January-March 1977.

Lyons, J. W. Fire Research and Fire Safety: A Status Report on the Situation in the United States. In: Fire Standards and Safety. Proceedings, pp. 5-10. National Bureau of Standards and the American Society for Testing Materials, Gaithersburg, Md., April 5-6, 1976. ASTM STP 614 (1977).

McCaffrey, B. J. and Berland, A. L. Some Observations on the Oscillatory Behavior of Carbon Monoxide Oxidation. Combustion and Flame, Vol. 26, No. 1, 77-83, 1976.

McCaffrey, B. J. and Quintiere, J. G. Buoyancy Driven Countercurrent Flows Generated by a Fire Source. In: Turbulent Buoyant Convection. 1976 International Seminar. Proceedings, pp. 467-478. International Centre for Heat and Mass Transfer, Dubrovnik, Yugoslavia, August 30-September 4, 1976.

McCarter, R. J. Smoldering of Flexible Polyurethane Foam. Journal of Consumer Product Flammability, Vol. 3, 128-140, June 1976. 
Packham, S. C., Frens, D. B., McCandless, J. B., Petajan, J. H. and Birky, M. M. A Chronic Intra-Arterial Cannula and Rapid MicroTechnicque for Carboxyhoglobin Determination. Journal of Combustion Toxicology, Vol. 3, 471-478, November 1976.

Parker, W. J. The Large-Scale Fire Test Facility at the National Bureau of Standards. In: Large-Scale Fire Tests. Symposium. Armstrong Research and Development Center. Proceedings, pp. 45-48, Lancaster, $\mathrm{Pa}$. , November 11-12, 1974 (1976).

Quintiere, J. G. Growth of Fire in Building Compartments. In: Fire Standards and Safety. Proceedings, pp. 300-311. National Bureau of Standards and the American Society for Testing Materials, Gaithersburg, Md., April 5-6, 1976. ASTM STP 614 (1977).

Robertson, A. F., Ed. Fire Standards and Safety. Proceedings. National Bureau of Standards and the American Society for Testing Matherials, Gaithersburg, Md., April 5-6, 1976. ASTM STP 614 (1977).

Robertson, A. F. Potential Heat: Considerations in the Application of a New Fire Test. Fire and Materials, Vol. 1, 9-13, March 1976.

Rockett, J. A. Fire Induced Gas Flow in an Enclosure. Combustion, Science and Technology, Vo1. 12, 165-175, 1976.

Tovey, H. and Vickers, A. Hazard Analysis of Fires Involving Blankets. Textile Chemist and Colorist, Vol. 8, No. 2, 19-22, February 1976.

II. National Burèau of Standards Publications

A. National Bureau of Standards Dimensions

McGehan, F. P. Life-Saving Investments: Smoke Detectors for the Home. NBS Dimensions, Vol. 60, No. 4, 6-8, April 1976. GPO; SD Catalog No. C13.13:60/4; $\$ 0.80$.

McGehan, F. P. Profile of a Firebug. NBS Dimensions, Vol. 60, No. 7, 12-13, July 1976. GPO; SD Catalog No. C13.13:60/7; $\$ 0.80$.

McGehan, F. P. Science and Fashion: NBS Develops Proposed Garment Flammability Guidelines. NBS Dimensions, Vol. 60, No. 6, 10-11;20, June 1976. GPO; SD Catalog No. C13.13:60/6; $\$ 0.80$.

Most Fire Deaths Occur at Home. NBS Dimensions, Vol. 60, No. 8, 21, August 1976. GPO; SD Catalog No. C13.13:60/8; \$0.80.

Moulder, J. L. Metal Fires - Science and Safety. NBS Dimensions, Vol. 60 , No. 1, 10-11, January 1976. GPO; SD Catalog No. C13.13:60/1; $\$ 0.80$. 
Science and Technology for People: Safety, Health, Public Benefit. NBS Dimensions, Vol. 60, Anniversary Supplement, 22-23, 1976. GPO; SD Catalog No. C13.13:60/Supp1.; \$0.80.

\section{B. National Bureau of Standards Interagency Reports}

NBSIR $75-788$

NBSIR 75-966

NBSIR 76-990

NBSIR 76-994

NBSIR $76-1000$

NBSIR 76-1012

NBSIR 76-1013

NBSIR 76-1014
Budnick, E. K. and Klein, D. P. Evaluation of the Fire Hazard in a Mobile Home Resulting from an Ignition on the Kitchen Range. February 1976. Interim Report. NTIS Order No. PB-250843; \$4.00.

Birky, M. M., Coats, A. E., Alderson, S. E., Brown, J. E., Paabo, M. and Pitt, B. Measurements and Observations of the Toxicological Hazard of Fire in a Metrorail Interior Mock-up. February 1976. Final Report. NTIS Order No. PB-250768; \$3.50.

Bright, R. G. Report of Fire Tests on Eight TGS Semiconductor Gas Sensor Residential Fire/Smoke Detectors. April 1976. Final Report. NTIS Order No. $251769 ; \$ 3.50$.

Brown, R. L. A Numerical Solution of the Time Dependent Partial Differential Equations Which Describe a One-Dimensional, Laminar, Premixed Flame. January 1976. Final Report. NTIS Order No. PB-263100; $\$ 7.50$.

Walker, J. A. and Tsang, W. The Contruction, Operation and Performance of a Reactive Gas Generator; with Specific Application to $\mathrm{HCHO}, \mathrm{CH}_{3} \mathrm{CHO}, \mathrm{CH}_{2} \mathrm{CHCHO}, \mathrm{SO}_{2}$, HCN and HCl Production. January 1976. Final Report. NTIS Order No. PB-251219; \$4.50.

Lee, B. T. Fire Performance Testing of Bulkhead Insulation Systems for High Strength to Weight Ship Structures. August 1976. Final Report. NTIS Order No. PB-257197; \$4.50.

Tu, K. M. and Davis, S. Flame Spread of Carpet Systems Involved in Room Fires. June 1976. Final Report. NTIS Order No. PB-256130; \$2.25.

Hayes, Jr., W. D. Space Heater Involvements in Fabric Fires. March 1976. Final Report. NTIS Order No. $\mathrm{PB}-251414$; $\$ 3.50$. 
NBSIR 76-1016 Gawin, W. M. and Bright, R. G. Mobile Home Smoke Detector Siting Study. May 1976. Final Report. NTIS Order No. PB-254177; \$4.50.

NBSIR 76-1018 Alderson, S. and Breden, L. Evaluation of the Fire Performance of Carpet Underlayments. September 1976. Final Report. NTIS Order No. PB-257779; \$4.50.

NBSIR 76-1021 Budnick, E. K. Fire Spread Along a Mobile Home Corridor. July 1976. Interim Report. NTIS Order No. PB-257101; \$4.50.

NBSIR 76-1028 Lay, D. A New Concept for Automatic Detection and Extinction of Fires. March 1976. Final Report. NTIS Order No. PB-251415; $\$ 3.50$.

NBSIR 76-1030 Breden, L. and Meisters, M. The Effect of Sample Orientation in the Smoke Density Chamber. May 1976. Final Report. NTIS Order No. PB-263633; \$4.00.

NBSIR 76-1031 Zerul1, R. Shape Dependence of Light-Scattering Behavior of Dust Particles. June 1976. Final Report. NTIS Order No. PB-253932; \$3.50.

NBSIR 76-1037 Kraus, F. J. Integral Measurement Procedures for Determining Particle Size in Aerosols. May 1976. Final Report. NTIS Order No. PB-253933; \$4.00.

NBSIR 76-1040 Schne11, M. Points of View in Testing Flame Detectors. May 1976. Final Report. NTIS Order No. PB-254178; $\$ 3.50$.

NBSIR 76-1052 Lee, B. T. and Parker, W. J. Naval Shipboard Fire Risk Criteria - Berthing Compartment Fire Study and Fire Performance Guidelines. September 1976. Final Report. NTIS Order No. PB-258118; $\$ 5.00$.

NBSIR 76-1054 Miller, D. B., Bower, V. E., Birky, M. M., Huggett, C. M. and Macek, A. An Appraisal of Tests and Standards for the Evaluation of Electrical Insulating Fluids. July 1976. Final Report. NTIS Order No. PB-253110; $\$ 5.50$.

NBSIR 76-1072 Braun, E., Cobble, V. B., Helzer, S., Krasny, J. F., Peacock, R. D. and Stratton, A. K. Back-up Report for the Proposed Standard for the Flammability of General Wearing Apparel. June 1976. Final Report. NTIS Order No. PB-255446; \$4.50. 
NBSIR $76-1076$

NBSIR 76-1087

NBSIR $76-1120$

NBSIR $76-1126$

NBSIR $76-1172$

FAA-RD-75-176

NBS-GCR-76-60

NBS-GCR-76-71

NBS-GCR-76-72

NBS-GCR-76-73
Macek, A. Flammability Limits: Thermodynamics and Kinetics. May 1976. Final Report. NTIS Order No. PB-254180; $\$ 4.00$.

Pistor, M. On a Scattering-Light Measuring Device for Use in Testing Types of Smoke Detectors. July 1976. Final Report. NTIS Order No. PB-257202; \$4.00.

Jason, N. H. Fire Research Publications, 1975. September 1976. Final Report. NTIS Order No. $\mathrm{PB}-257837$; $\$ 3.50$.

Bukowski, R. W. Field Investigation of Residential Smoke Detectors. November 1976. Final Report. NTIS Order No. PB-260878; $\$ 4.50$.

Bright, R. G. A New Test Method for Automatic Fire Detection Devices. December 1976. Final Report. NTIS Order No. PB-261217; $\$ 4.00$.

\section{Contract and Grant Reports}

Braun, E., Cobble, V. B., Krasny, J. F. and Peacock, R. Development of a Proposed Flammability Standard for Commerial Transport Flight Attendant Uniforms. Final Report. U.S. Department of Transportation. Contract No. DOT-FA75WA1-502. NTIS Order No. AD/A-033740; \$7.50.

Balanoff, T. Fire Fighter Mortality Report. International Association of Fire Fighters, Washington, D.C. March 1976. Final Report. NBS Grant No. 4-35909. NTIS Order No. PB-253588; \$6.75.

Tesoro, G. and Backer, S. Extinguishment in Appare1 Textiles. Massachusetts Institute of Technology. October 1975. Final Report. NBS Grant No. 4-9024. NTIS Order No. PB-254751; \$4.50.

Labes, W. G. Evaluation of Fire Protection Spray Devices: The State-of-the-Art. Illinois Institute of Technology. June 30, 1976. Final Report. NBS Grant No. 5-9015. NTIS Order No. PB-256190; \$5.50.

Lerup, L., Greenwood, D. and Burke, J. S. Mapping of Recurrent Behavior Patterns in Institutional Buildings Under Fire: Ten Case Studies of Nursing Facilities. University of California at Berkeley. July 1976. Final Report. HEW/NBS Life/Fire Safety Program Grant No. 5-9016. NTIS Order No. PB-257424; $\$ 6.75$. 
NBS-GCR-76-77 Miles, L. B. A Basic Investigation of the Extinguishability of Various Fabrics. University of Maryland Master of Science Thesis. May 1976. NBS Grant No. 4-9019. NTIS Order No. PB-257767; \$5.00.

NBS-GCR-76-78 Stratton, A. K. An Investigation of Certain Design Parameters of the Mushroom Apparel Flammability Tester. University of Maryland Master of Science Thesis. July 1976. NBS Grant No. 4-9010. NTIS Order No. PB-247836; $\$ 5.50$.

NBS-GCR-76-79 Dryer, F. L., Glassman, I. and Sirignano, W. A. A Problem in Fire Safety: Flame Spreading Across Liquid Fuels. Princeton University. September 15, 1976. Final Report. NFPCA Grant No. AEN-7514285. NTIS Order No. PB-259127; $\$ 4.00$.

NBS-GCR-76-80 Markstein, G. H. Scaling of Radiative Characteristics of Turbulent Diffusion Flames. Factory Mutual Research Corporation. June 1976. Final Report. NFPCA Contract No. 75-004. NTIS Order No. PB-259126; $\$ 4.50$. 
IV. Author Index

A

Adams, C. H., 1

Alderson, S. E., 1, 4, 5

B

Backer, S., 6

Balanoff, T., 6

Benjamin, I. A., 1

Berland, A. L., 2

Birky, M. M., 1, 3, 4, 5

Bower, V. E., 5

Braun, E., 2, 5, 6

Breden, L. H., 1, 5

Bright, R. G., 1, 4, 5, 6

Brown, J. E., 1, 4

Brown, R. L., 4

Budnick, E. K., 4, 5

Bukowski, R. W., 6

Burke, J. S., 6

\section{C}

Cheng, I. T., 2

Clarke, III, F. B., 1

Coats, A. W., 1, 4

Cobble, V. B., 5, 6

Davis, S., 1, 4

Dryer, F. L., 7

E

Einhorn, I. N., I

F

Fang, J. B., 2

Frens, D. B., 3

Fung, F. C. S., 2
G

Gann, R. G., 2

Gawin, W. M., 5

Glassman, I., 7

Greenwood, D., 6

Gross, D., 2

$\mathrm{H}$

Hayes, Jr., W. D., 4

Helzer, S., 5

Hileman, F. D., 1

Huggett, C. M., 5

$\mathrm{J}$

Jason, N. H, , 6

K

Kashiwagi, T., 2

Klein, D. P., 4

Krasny, J. F., 2, 5, 6

Kraus, F, J, , 5

L

Labes, W. G., 6

Lay, D., 5

Lee, B. T., 4, 5

Lerup, L., 6

Levin, B., 2

Lyons, J. W., 2

M

Macek, A., 5, 6

Markstein, G. H., 7

McCaffrey, B. J., 2

McCandless, J. B., 3

McCarter, R. J., 2 
McGehan, F. P., 3

Meisters, M., 1, 5

Miles, L. B., 7

Miller, D. B., 5

Moulder, J. L., 3

$\mathrm{N}$

Newman, D. L., 2

0

Ottoson, J., 1

P

Paabo, M., 4

Packham, S. C., 3

Parker, W. J., 3, 5

Peacock, R. W., 5, 6

Petajan, J. H., 3

Pistor, M., 6

Pitt, B., 1, 4

Q

Quintiere, J. G., 2, 3

R

Ramakrishman, M. S., 1

Robertson, A. F., 3

Rockett, J. A., 3

Ryan, P. W., 1

\section{$\mathrm{S}$}

Schne11, M., 5

Sirignano, W. A., 7

Stratton, A. K., 5, 7
Tesoro, G., 6

Tovey, H., 3

Tsang, W., 4

$\mathrm{Tu}, \mathrm{K}-\mathrm{M}, 4$

V

Vickers, A., 3

Voorhees, K. T., 1

W

Walker, J. A., 4

Wojcik, L. H., 1

Z

Zerul1, R., 5 
NBS-114A (REV.\%73)

\begin{tabular}{|c|c|c|c|}
\hline $\begin{array}{l}\text { U.S. DEPT. OF COMM. } \\
\text { BIBLIOGRAPHIC DATA } \\
\text { SHEET }\end{array}$ & $\begin{array}{l}\text { I. IUIBL.IC ATION (OR RI:IORT NO. } \\
\text { NBSIR 77-1277 }\end{array}$ & $\begin{array}{l}\text { 2. (jov'l Arcossion } \\
\text { No. }\end{array}$ & 3. Recipicolt's $A_{t}$ cossicul $\mathrm{N}_{11}$. \\
\hline 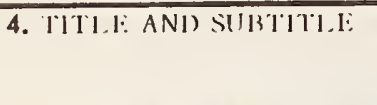 & & & $\begin{array}{l}\text { 5. Publication 1)atc } \\
\text { July } 1977\end{array}$ \\
\hline \multicolumn{3}{|c|}{ Fire Research Publications, 1976} & 6. Performing Organizaltion ( oxle \\
\hline \multicolumn{3}{|l|}{$\begin{array}{l}\text { 7. AU'illor(S) } \\
\text { Nora H. Jason }\end{array}$} & 8. Perforning Orgall. Report No. \\
\hline \multirow{2}{*}{\multicolumn{3}{|c|}{$\begin{array}{l}\text { 9. PERI:ORMING ORGANIZATION NAME AND ADDRESS } \\
\text { NATIONAL BUREAU OF STANDARDS } \\
\text { DEPARTMENT OF COMMERCE } \\
\text { WASHINGTON, D.C. } 20234\end{array}$}} & $\begin{array}{l}\text { 10. Project/Task/Work Init No. } \\
4913678\end{array}$ \\
\hline & & & 11. Contract/Grant No. \\
\hline \multirow{2}{*}{\multicolumn{3}{|c|}{ 12. Sponsoring Organization Name and Complete Address (Street, City, State, ZIP) }} & $\begin{array}{l}\text { 13. Type of Report \& Period } \\
\text { Covered } \\
\text { Final Report }\end{array}$ \\
\hline & & & 14. Sponsoring Agency Code \\
\hline
\end{tabular}

16. ABSTRACT (A 200-word or less factual summary of most significant information. If document includes a significant bibliography or literature survey, mention it here.)

"Fire Research Publications, 1976" is a supplement to the previous editions which covered the years 1y69-1972 (NBSIR 73-246, NTIS Order No. COM-7410989; \$3.25), 1973 (NBSIR 74-511, NTIS Order No. COM-74-11448; \$3.25), 1974 (NBSIR 75-736, NTIS Order No. COM-75-11018; \$3.25), and 1975 (NBSIR 76-1120, NTIS Order No. PB-257837; \$3.50). Only publications prepared by the members of the Center for Fire Research (CFR), by other National Bureau of Standards (NBS) personnel or external laboratories under contract or grant from the CFR are cited. Articles published in NBS house organs also are cited.

17. KEY WORDS (six to twelve entries; alphabetical order; capitalize only the first letter of the first key word unless a proper name; separated by semicolons) Arson; bibliographies; building fires; carpets; construction materials; fire departments; fire detection systems; fire tests; flame research; flammability tests; interior furnishings; mobile homes; polyurethanes; smoke detectors; standards; textiles; toxicity

18. AVAILABILITY $\mathbf{x}$ Unlimited

For Official Distribution. Do Not Release to NTIS

Order From Sup. of Doc., U.S. Government Printing Office Washington, D.C. 20402, SD Cat. No. C13

\begin{tabular}{|l|c|}
\hline $\begin{array}{l}\text { 19. SECURITY CLASS } \\
\text { (THIS REPURT) }\end{array}$ & 21. NO. OF PAGES \\
UNCL ASSIFIED & 13 \\
\hline $\begin{array}{l}\text { 20. SECURITY CLASS } \\
\text { (THIS PAGE) } \\
\text { UNCLASSIFIED }\end{array}$ & 22. Price \\
\end{tabular}

X Order From National Technical Information Service (NTIS) Springfield, Virginia 22151 